\title{
Investigation and Analysis of Catheter-Associated Skin Impairment in PICC's Patients in Jingzhou City
}

\author{
Qianwen Li1, Hong Wang2*, Feifan Liư ${ }^{1}$, Yiqing He ${ }^{1}$ \\ ${ }^{1}$ Yangtze University, Jingzhou, China \\ ${ }^{2}$ Jingzhou Central Hospital, Jingzhou, China \\ Email:981100593@qq.com, ^1727923224@qq.com
}

How to cite this paper: Li, Q.W., Wang, H., Liu, F.F. and He, Y.Q. (2020) Investigation and Analysis of Catheter-Associated Skin Impairment in PICC's Patients in Jingzhou City. Journal of Biosciences and Medicines, $\mathbf{8}$, 38-46.

https://doi.org/10.4236/jbm.2020.810005

Received: September 4, 2020

Accepted: October 11, 2020

Published: October 14, 2020

Copyright $\odot 2020$ by author(s) and Scientific Research Publishing Inc. This work is licensed under the Creative Commons Attribution International License (CC BY 4.0).

http://creativecommons.org/licenses/by/4.0/

\begin{abstract}
Objective: To understand the status quo of PICC Catheter-associated Skin Impairment (CASI) in some hospitals at all levels in Jingzhou city, and to explore the risk factors for PICC Catheter-associated Skin Impairment. Methods: From June 2019 to July 2020, a self-made questionnaire for CASI status was used to facilitate the extraction of CASI patients in PICC in some hospitals at all levels in Jingzhou city. Local skin lesions were collected and classified during PICC maintenance, and the damage types, occurrence frequency and related influencing factors of CASI were counted to identify independent risk factors. Results: In this study, there were 173 cases of CASI in PICC's patients including local infection 56.1\% (97/173), exudation at the puncture site $16.8 \%(29 / 173)$, irritant dermatitis $21.4 \%$ (37/173), allergic dermatitis $4.6 \%$ (8/173), and tension injury $1.2 \%$ (2/173). After univariate analysis, there were statistically significant differences between CASI occurrence type and duration of catheter wear, age, underlying disease, skin moisture and hyperhidrosis, PICC maintenance as required, hospital grade maintenance and intermittent chemotherapy $(\mathrm{P}<0.05)$. Then, disordered multiple Logistic regression analysis was performed, and exudation at the puncture site was used as the reference group. The results showed that patients with PICC were more likely to have CASI if they were aged, long catheter time, had diabetes, had moist and sweaty skin, and were in the intermittent stage of chemotherapy. Conclusion: The incidence of CASI is high in patients aged $70-79$ years, and local infection is the most common. PICC's patients with diabetes are at high risk of CASI. PICC's patients with excessive sweating are more likely to have CASI. The intermittent stage of chemotherapy is the excessive CASI; time with tube affects CASI occurrence.
\end{abstract}




\section{Keywords}

PICC, CASI, Status Survey, Multifactor Analysis

\section{Introduction}

At present, there is no uniform definition of CASI. Broadhurst et al., based on Medical Adhesive Skin Iesion (MARSI), and Catheter-associated Skin Impairment (CASI), refer to various skin abnormalities, including pus, red patches, erosion, or tearing, occurring in the PICC Catheter site and surrounding skin [1]. CASI mainly includes contact dermatitis, mechanical injury, puncture point exudation, local infection and pressure injury [1]. In domestic studies, there are few studies on CASI, and medical workers pay more attention to contact dermatitis, MARSI and exudation at the puncture site of PICC implantation [2] [3]. Therefore, taking CASI as the starting point, this study made a self-made survey tool for PICC Catheter-associated Skin Impairment, investigated the current situation of CASI occurrence in PICC's patients in some hospitals at all levels in Jingzhou city, and discussed the risk factors for PICC Catheter-associated Skin Impairment.

\section{Objects and Methods}

\subsection{Research Objects}

A self-made CASI status questionnaire was used from June 2019 to July 2020, and the samples were randomly selected CASI occurred in 173 patients with PICC in some hospitals at all levels in Jingzhou City. Inclusion criteria: (1) PICC's patients have been carried out; (2) Age $\geq 18$ years old; (3) The patient has no cognitive, verbal or intellectual dysfunction; (4) Patients who volunteered to participate in the study. Exclusion criteria: (1) Congenital or pre-existing skin diseases; (2) Patients with skin allergy. 173 patients were included in this study, including head and neck tumor (nasopharyngeal carcinoma in 10 cases; 3 cases of laryngeal cancer); Thoracic tumors (8 cases of esophageal cancer; Lung cancer in 27 cases); 40 cases of breast cancer; Abdominal tumor (gastric cancer in 10 cases; Three cases of liver cancer; One case of colon cancer; 11 cases of rectal cancer; 7 cases of pancreatic cancer); Female reproductive system tumors (cervical cancer: 3 cases; 13 cases of ovarian malignant tumor; 4 cases of fallopian tube malignant tumor; Endometrial carcinoma (3 cases); Hemolytic lymphatic system tumors (leukaemia: 11 cases; 3 cases of bone marrow carcinoma; Lymphoma was found in 6 patients. Severe aplastic anemia: 1 case); Tumor of central nervous system ( 7 cases of intracranial tumor).

\subsection{Research Methods}

\subsubsection{Research Tools}

The "CASI questionnaire" was designed by myself by referring to literature and combining with clinical experience, and then Delphi was conducted in this study, 3 rounds of expert consultation were conducted, and 11 experts partici- 
pated in the consultation process. Their professional directions include nursing management, nursing research, nursing education and clinical nursing. Finally, a questionnaire was formed after expert consultation for data collection. The questionnaire is mainly divided into four parts: general information (gender, education background, age, BMI, smoking history and drinking history); The patient's disease information; PICC and maintenance information; CASI information (type of occurrence).

\subsubsection{Survey Methods}

Three weeks before the study, the investigators were trained on CASI knowledge and precautions. The general data of the questionnaire, disease data, PICC and Maintenance data section were obtained and recorded by inquiring or consulting the inpatient medical records of the study subjects, catheter data and catheter maintenance manual. The data of CASI were based on the abnormal conditions of the local skin of the PICC's patients, and the investigators determined the type of CASI occurrence according to the relevant training knowledge, and filled in the specific time of occurrence.

\subsection{Statistical Treatment}

SPSS19.0 statistical software was used for data analysis and processing, and descriptive analysis was conducted for counting data frequency, percentage, measurement data mean and standard deviation. Input all CASI data and related information into SPSS19.0, and statistically describe and analyze the occurrence of all types of CASI. Univariate analysis of variance (ANOVA) and Chi-square test was used to analyze the influencing factors of CASI, and P < 0.05 was considered statistically significant. Univariate analysis of variance (ANOVA) and Chi-square test $(\mathrm{P}<0.05)$ were then included in the Logistic regression model for unordered multiple classification Logistic regression analysis, and $\mathrm{P}<0.05$ was considered as statistically significant difference.

\section{The Results}

1) Occurrence of CASI, a total of 173 cases of CASI were included in this study, among which local infection, puncture site exudation, mechanical injury and contact dermatitis occurred in sequence. See Table 1 for details.

2) Influence factor analysis of CASI in PICC's patients through single factor analysis of different observation items. The results showed that the duration of the catheter, age, basic diseases, wet and sweaty skin, PICC maintenance as required, hospital grade maintenance and chemotherapy intermission were statistically significant are shown in Table 2.

3) Patients with PICC CASI more disorderly classification to the single factor

Logistic regression analysis, chi-square analysis was statistically significant with tube time, age, basic diseases, skin is damp sweat, if according to the provisions of PICC maintenance, maintenance level of hospital and whether in intermittent chemotherapy period more than seven influencing factors into the disorderly 
Table 1. CASI incidence in 173 patients with PICC.

\begin{tabular}{lccccc}
\hline & & \multicolumn{2}{c}{ Contact dermatitis } & $\begin{array}{c}\text { Mechanical } \\
\text { damage }\end{array}$ \\
\hline & Local infection & $\begin{array}{c}\text { Exudation at the } \\
\text { puncture site }\end{array}$ & $\begin{array}{c}\text { Irritant } \\
\text { dermatitis }\end{array}$ & $\begin{array}{c}\text { Allergic } \\
\text { dermatitis }\end{array}$ & $\begin{array}{c}\text { Tension } \\
\text { damage }\end{array}$ \\
\hline The number of cases & 97 & 29 & 37 & 8 & 2 \\
The percentage (\%) & 56.1 & 16.8 & 21.4 & 4.6 & 1.2 \\
\hline
\end{tabular}

Table 2. Single factor analysis of CASI in PICC's patients.

\begin{tabular}{|c|c|c|c|c|c|c|c|c|c|c|c|c|c|c|}
\hline & & \multicolumn{2}{|c|}{ Local infection } & \multicolumn{2}{|c|}{$\begin{array}{l}\text { Exudation at } \\
\text { the puncture site }\end{array}$} & \multicolumn{4}{|c|}{ Contact dermatitis } & \multirow{2}{*}{\multicolumn{2}{|c|}{$\begin{array}{c}\begin{array}{c}\text { Mechanical } \\
\text { damage }\end{array} \\
\text { Tension damage }\end{array}$}} & \multirow{3}{*}{$\begin{array}{l}\text { The } \\
\text { number } \\
\text { of cases }\end{array}$} & \multirow[t]{3}{*}{$F / X^{2}$} & \multirow[t]{3}{*}{$P$} \\
\hline & & \multirow[b]{2}{*}{ 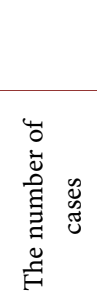 } & \multirow[b]{2}{*}{ 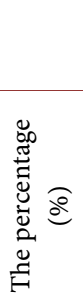 } & \multirow[b]{2}{*}{ 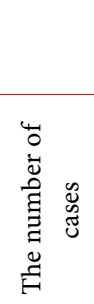 } & \multirow[b]{2}{*}{ 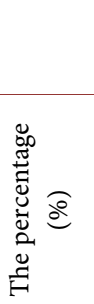 } & \multicolumn{2}{|c|}{$\begin{array}{c}\text { Irritant } \\
\text { dermatitis }\end{array}$} & \multicolumn{2}{|c|}{$\begin{array}{l}\text { Allergic } \\
\text { dermatitis }\end{array}$} & & & & & \\
\hline & & & & & & 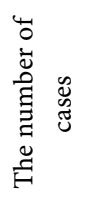 & 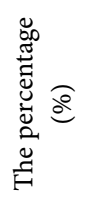 & 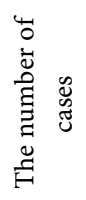 & 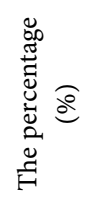 & 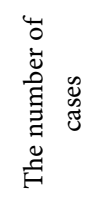 & 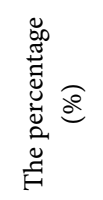 & & & \\
\hline \multirow{3}{*}{ Gender } & & & & & & & & & & & & & 1.86 & 0.635 \\
\hline & Female & 45 & 46.40 & 11 & 37.90 & 16 & 43.20 & 4 & 50.00 & 0 & 0.00 & 76 & & \\
\hline & Male & 52 & 53.60 & 18 & 62.10 & 21 & 56.80 & 4 & 50.00 & 2 & 100.00 & 97 & & \\
\hline \multirow{5}{*}{ Age } & & & & & & & & & & & & & 22.07 & 0.014 \\
\hline & $18-39$ & 11 & 11.30 & 6 & 20.70 & 5 & 13.50 & 0 & 0.00 & 0 & 0.00 & 22 & & \\
\hline & $40-59$ & 17 & 17.50 & 11 & 37.90 & 8 & 21.60 & 3 & 37.50 & 1 & 50.00 & 40 & & \\
\hline & $60-69$. & 40 & 41.20 & 11 & 37.90 & 20 & 54.10 & 5 & 62.50 & 1 & 50.00 & 77 & & \\
\hline & $70-79$. & 29 & 29.90 & 1 & 3.40 & 4 & 10.80 & 0 & 0.00 & 0 & 0.00 & 34 & & \\
\hline \multirow{6}{*}{ BMI } & & & & & & & & & & & & & 20.08 & 0.186 \\
\hline & $\begin{array}{l}\text { Normal: } \\
18.5-23.9\end{array}$ & 67 & 69.10 & 19 & 65.50 & 21 & 56.80 & 5 & 62.50 & 2 & 100.00 & 114 & & \\
\hline & $\begin{array}{l}\text { Overweight: } \\
24 \text { or more }\end{array}$ & 15 & 15.50 & 3 & 10.30 & 4 & 10.80 & 0 & 0.00 & 0 & 0.00 & 22 & & \\
\hline & $\begin{array}{l}\text { Overweight: } \\
24-27.9\end{array}$ & 6 & 6.20 & 0 & 0.00 & 5 & 13.50 & 2 & 25.00 & 0 & 0.00 & 13 & & \\
\hline & $\begin{array}{l}\text { Obesity: } \\
28 \text { or higher }\end{array}$ & 2 & 2.10 & 0 & 0.00 & 0 & 0.00 & 0 & 0.00 & 0 & 0.00 & 2 & & \\
\hline & Lean: 18.5 or less & 7 & 7.20 & 7 & 24.10 & 7 & 18.90 & 1 & 12.50 & 0 & 0.00 & 22 & & \\
\hline \multirow{6}{*}{$\begin{array}{l}\text { Record of formal } \\
\text { schooling }\end{array}$} & & & & & & & & & & & & & 14.89 & 0.247 \\
\hline & Illiteracy & 6 & 6.20 & 1 & 3.40 & 3 & 8.10 & 2 & 25.00 & 0 & 0.00 & 12 & & \\
\hline & Primary school & 23 & 23.70 & 12 & 41.40 & 12 & 32.40 & 1 & 12.50 & 1 & 50.00 & 49 & & \\
\hline & Junior high school & 30 & 30.90 & 5 & 17.20 & 11 & 29.70 & 1 & 12.50 & 0 & 0.00 & 47 & & \\
\hline & High school & 21 & 21.60 & 2 & 6.90 & 7 & 18.90 & 3 & 37.50 & 0 & 0.00 & 33 & & \\
\hline & $\begin{array}{c}\text { Junior College and } \\
\text { above }\end{array}$ & 17 & 17.50 & 9 & 31.00 & 4 & 10.80 & 1 & 12.50 & 1 & 50.00 & 32 & & \\
\hline
\end{tabular}




\section{Continued}

\begin{tabular}{|c|c|c|c|c|c|c|c|c|c|c|c|c|c|c|}
\hline & & & & & & & & & & & & & 23.58 & 0.04 \\
\hline \multirow{6}{*}{ Basic diseases } & No & 38 & 39.20 & 20 & 69.00 & 25 & 67.60 & 3 & 37.50 & 1 & 50.00 & 87 & & \\
\hline & $\begin{array}{c}\text { Liver and kidney } \\
\text { disease }\end{array}$ & 8 & 8.20 & 2 & 6.90 & 1 & 2.70 & 2 & 25.00 & 0 & 0.00 & 13 & & \\
\hline & Hypertension & 11 & 11.30 & 0 & 0.00 & 1 & 2.70 & 0 & 0.00 & 0 & 0.00 & 12 & & \\
\hline & Anemia & 3 & 3.10 & 3 & 10.30 & 3 & 8.10 & 0 & 0.00 & 0 & 0.00 & 9 & & \\
\hline & Diabetes & 33 & 34.00 & 3 & 10.30 & 6 & 16.20 & 3 & 37.50 & 1 & 50.00 & 46 & & \\
\hline & Heart disease & 4 & 4.10 & 1 & 3.40 & 1 & 2.70 & 0 & 0.00 & 0 & 0.00 & 6 & & \\
\hline \multirow{3}{*}{$\begin{array}{l}\text { Whether the skin is } \\
\text { moist and sweaty }\end{array}$} & & & & & & & & & & & & & 20.61 & 0.000 \\
\hline & Yes & 69 & 71.10 & 9 & 31.00 & 28 & 75.70 & 6 & 75.00 & 0 & 0.00 & 112 & & \\
\hline & No & 28 & 28.90 & 20 & 69.00 & 9 & 24.30 & 2 & 25.00 & 2 & 100.00 & 61 & & \\
\hline The tube time & \multicolumn{12}{|c|}{$66.91+/-56.12$} & 1.584 & 0.02 \\
\hline \multirow{3}{*}{ Catheter site } & & & & & & & & & & & & & 2.12 & 0.564 \\
\hline & Upper left & 38 & 39.20 & 10 & 34.50 & 19 & 51.40 & 3 & 37.50 & 1 & 50.00 & 71 & & \\
\hline & Upper right & 59 & 60.80 & 19 & 65.50 & 18 & 48.60 & 5 & 62.50 & 1 & 50.00 & 102 & & \\
\hline \multirow{3}{*}{ PICC type } & & & & & & & & & & & & & 4.66 & 0.191 \\
\hline & Triple valve type & 89 & 91.80 & 27 & 93.10 & 29 & 78.40 & 7 & 87.50 & 2 & 100.00 & 154 & & \\
\hline & $\begin{array}{l}\text { Resistance to high } \\
\text { pressure type }\end{array}$ & 8 & 8.20 & 2 & 6.90 & 8 & 21.60 & 1 & 12.50 & 0 & 0.00 & 19 & & \\
\hline \multirow{3}{*}{$\begin{array}{l}\text { Whether to } \\
\text { maintain PICC } \\
\text { according to } \\
\text { regulations }\end{array}$} & & & & & & & & & & & & & 10.87 & 0.01 \\
\hline & Yes & 82 & 84.50 & 28 & 96.60 & 37 & 100.00 & 8 & 100.00 & 2 & 100.00 & 157 & & \\
\hline & No & 15 & 15.50 & 1 & 3.40 & 0 & 100.00 & 0 & 100.00 & 0 & 100.00 & 16 & & \\
\hline \multirow{3}{*}{$\begin{array}{l}\text { Maintain hospital } \\
\text { grade }\end{array}$} & & & & & & & & & & & & & 10.45 & 0.009 \\
\hline & The secondary & 60 & 61.90 & 16 & 55.20 & 14 & 37.80 & 2 & 25.00 & 0 & 0.00 & 92 & & \\
\hline & Level 3 & 37 & 38.10 & 13 & 44.80 & 23 & 62.20 & 6 & 75.00 & 2 & 100.00 & 81 & & \\
\hline \multirow{3}{*}{$\begin{array}{l}\text { Maintenance } \\
\text { personnel }\end{array}$} & & & & & & & & & & & & & 1.92 & 0.572 \\
\hline & $\begin{array}{l}\text { PICC's specialist } \\
\text { nurse }\end{array}$ & 23 & 23.70 & 10 & 34.50 & 10 & 27.00 & 3 & 37.50 & 0 & 0.00 & 46 & & \\
\hline & $\begin{array}{c}\text { In-hospital } \\
\text { training of nurses }\end{array}$ & 74 & 76.30 & 19 & 65.50 & 27 & 73.00 & 5 & 62.50 & 2 & 100.00 & 127 & & \\
\hline \multirow{3}{*}{$\begin{array}{l}\text { Interchemotherapy } \\
\text { period }\end{array}$} & & & & & & & & & & & & & 8.64 & 0.023 \\
\hline & Yes & 45 & 46.40 & 5 & 17.20 & 16 & 43.20 & 1 & 12.50 & 1 & 50.00 & 68 & & \\
\hline & No & 52 & 53.60 & 24 & 82.80 & 21 & 56.80 & 7 & 87.50 & 1 & 50.00 & 105 & & \\
\hline
\end{tabular}

classification Logistic regression analysis, the independent variable assignment are shown in Table 3. With exudation at the puncture site as the reference group, the results showed that PICC's patients with catheter duration of 150 - 199 days, diabetes, moist and sweaty skin, and intermittent chemotherapy were more likely to have local infection of CASI (OR > 1.0, P < 0.05). PICC's patients with moist and sweaty skin and intermittent chemotherapy were more likely to develop contact dermatitis with CASI (OR $>1.0, \mathrm{P}<0.05)$. Compared with patients aged $70-79$ 
Table 3. Assignment methods of independent variables.

\begin{tabular}{|c|c|}
\hline The independent variables & Assignment way \\
\hline The tube time & $1-49=1 ; 50-99=2 ; 100-149=3 ; 150-199=4 ; \geq 5200$ \\
\hline Age & $18-39=1 ; 40-59=2 ; 60-69=3 ; 70-79=4$ \\
\hline Basic diseases & $\begin{aligned} \text { No }= & 1 ; \text { Liver and kidney disease }=2 ; \text { Hypertension }=3 ; \\
& \text { Anemia }=4 ; \text { Diabetes }=5 ; \text { Heart disease }=6\end{aligned}$ \\
\hline Maintain hospital grade & Level $2=1 ;$ Level $3=2$ \\
\hline Whether the skin is moist and sweaty & Yes $=1 ; \mathrm{No}=2$ \\
\hline Whether to maintain according to regulations & Yes $=1 ;$ No $=2$ \\
\hline Whether in the chemotherapy intermission period & $\mathrm{Yes}=1 ; \mathrm{No}=2$ \\
\hline
\end{tabular}

Table 4. Multivariate logistic regression analysis of CASI influencing factors.

\begin{tabular}{|c|c|c|c|c|c|c|c|c|c|c|c|c|c|c|c|c|}
\hline \multirow{3}{*}{\multicolumn{2}{|c|}{ Value }} & \multicolumn{5}{|c|}{ Local infection } & \multicolumn{5}{|c|}{ Contact dermatitis } & \multicolumn{5}{|c|}{ Mechanical damage } \\
\hline & & \multirow[t]{2}{*}{ B } & \multirow[t]{2}{*}{$\mathrm{P}$} & \multirow[t]{2}{*}{$\begin{array}{l}\text { The OR } \\
\text { Value }\end{array}$} & \multicolumn{2}{|c|}{$95 \% \mathrm{CI}$} & \multirow[t]{2}{*}{ B } & \multirow[t]{2}{*}{$\mathrm{P}$} & \multirow[t]{2}{*}{$\begin{array}{c}\text { The OR } \\
\text { Value }\end{array}$} & \multicolumn{2}{|c|}{$95 \% \mathrm{CI}$} & \multirow[t]{2}{*}{ B } & \multirow[t]{2}{*}{$\mathrm{P}$} & $\begin{array}{l}\text { The OR } \\
\text { Value }\end{array}$ & \multicolumn{2}{|c|}{$95 \% \mathrm{CI}$} \\
\hline & & & & & $\begin{array}{l}\text { The } \\
\text { lower } \\
\text { limit }\end{array}$ & Ceiling & & & & $\begin{array}{l}\text { The } \\
\text { lower } \\
\text { limit }\end{array}$ & Ceiling & & & & $\begin{array}{l}\text { The } \\
\text { lower } \\
\text { limit }\end{array}$ & Ceiling \\
\hline \multirow{5}{*}{ The tube time } & $1-49$ & -13.24 & 0.996 & 0.00 & 0.00 &.$b$ & -15.43 & 0.995 & 0.00 & 0.00 &.$b$ & -70.70 & 0.998 & 0.00 & 0 &.$b$ \\
\hline & $50-99$ & -8.48 & 0.997 & 0.00 & 0.00 &.$b$ & -11.40 & 0.997 & 0.00 & 0.00 &.$b$ & -83.77 & 0.998 & 0.00 & 0 &.$b$ \\
\hline & $100-149$ & -11.35 & 0.997 & 0.00 & 0.00 &.$b$ & -14.26 & 0.996 & 0.00 & 0.00 &.$b$ & -54.57 & 0.999 & 0.00 & 0 &.$b$ \\
\hline & $150-199$ & 4.23 & 0.017 & 68.66 & 2.15 & 2189.10 & 1.05 & . & 2.87 & 2.87 & 2.87 & -40.53 & 0.999 & 0.00 & 0 &.$b$ \\
\hline & $>200$ & $0 \mathrm{c}$ & . & . & . & . & $0 \mathrm{c}$ & . & . & . & . & $0 \mathrm{c}$ & . & . & . & . \\
\hline \multirow{3}{*}{ Age } & $40-59$ & -4.95 & 0.002 & 0.01 & 0.00 & 0.17 & -2.87 & 0.094 & 0.06 & 0.00 & 1.62 & 27.19 & 0.996 & $6^{*} 10^{* 12}$ & 0 &.$b$ \\
\hline & $60-69$ & -3.28 & 0.034 & 0.04 & 0.00 & 0.77 & -1.23 & 0.448 & 0.29 & 0.01 & 7.00 & -2.41 & 1.00 & 0.09 & 0 &.$b$ \\
\hline & $70-79$ & $0 \mathrm{c}$ & . & . & . & . & $0 \mathrm{c}$ & . & . & . & . & $0 \mathrm{c}$ & . & . & . & . \\
\hline \multirow{6}{*}{ Basic diseases } & No & 1.41 & 0.368 & 4.09 & 0.19 & 87.23 & 2.08 & 0.237 & 7.99 & 0.26 & 249.50 & -26.12 & 0.998 & 0.00 & 0 &.$b$ \\
\hline & $\begin{array}{c}\text { Liver and } \\
\text { kidney disease }\end{array}$ & 2.72 & 0.152 & 15.10 & 0.37 & 622.62 & 2.56 & 0.224 & 12.95 & 0.21 & 803.94 & -23.54 & 0.999 & 0.00 & 0 &.$b$ \\
\hline & Hypertension & 19.93 & 0.995 & $4 \times 10^{* 9}$ & 0.00 &.$b$ & 18.37 & 0.996 & $9 \times 10^{* 9}$ & 0.00 &.$b$ & -41.45 & 0.998 & 0.00 & 0 &.$b$ \\
\hline & Anemia & -0.25 & 0.891 & 0.78 & 0.02 & 25.87 & 1.48 & 0.445 & 4.41 & 0.10 & 198.30 & -12.73 & 0.999 & 0.00 & 0 &.$b$ \\
\hline & Diabetes & 4.04 & 0.028 & 57.03 & 1.53 & 2120.89 & 3.95 & 0.052 & 51.72 & 0.96 & 2788.52 & -8.94 & 1.00 & 0.00 & 0 &.$b$ \\
\hline & Heart disease & $0 \mathrm{c}$ & . & . & . & . & $0 \mathrm{c}$ & . & . & . & . & $0 \mathrm{c}$ & . & . & . & . \\
\hline \multirow{2}{*}{$\begin{array}{l}\text { Whether the } \\
\text { skin is moist } \\
\text { and sweaty }\end{array}$} & Yes & 1.88 & 0.006 & 6.58 & 1.72 & 25.21 & 1.95 & 0.004 & 7.03 & 1.88 & 26.30 & -30.40 & 0.986 & $<0.000$ & 0 &.$b$ \\
\hline & No & $0 \mathrm{c}$ & . & . & . & . & $0 \mathrm{c}$ & . & . & . & . & $0 \mathrm{c}$ & . & . & . & . \\
\hline \multirow{2}{*}{$\begin{array}{l}\text { Whether to } \\
\text { maintain } \\
\text { according to } \\
\text { regulations }\end{array}$} & Yes & -1.93 & 0.371 & 0.15 & 0.00 & 9.94 & 16.15 & . & $10^{*} 8$ & $10^{\star} 8$ & $10^{\star} 8$ & -15.86 & 0.998 & $<0.000$ & 0 &.$b$ \\
\hline & No & $0 \mathrm{c}$ & . & . & . & . & $0 \mathrm{c}$ & . & . & . & . & $0 \mathrm{c}$ & . & . & . & . \\
\hline \multirow{2}{*}{$\begin{array}{l}\text { Whether in the } \\
\text { chemotherapy } \\
\text { intermission } \\
\text { period }\end{array}$} & Yes & 1.92 & 0.009 & 6.80 & 1.63 & 28.41 & 1.55 & 0.031 & 4.73 & 1.16 & 19.37 & 16.41 & 0.993 & $10^{\star} 8$ & 0 &.$b$ \\
\hline & No & $0 \mathrm{c}$ & . & . & . & . & $0 c$ & . & . & . & . & $0 \mathrm{c}$ & . & . & . & . \\
\hline
\end{tabular}


years, patients aged 18 - 69 years were less likely to develop local infection of CASI, OR $<1.0, \mathrm{P}<0.05$, and patients aged $70-79$ years were more likely to develop local infection of CASI. As shown in Table 4.

\section{Discuss}

In this study, there were 173 cases of CASI, including 56.1\% (97/173) of local infection, $16.8 \%$ (29/173) of exudation at the puncture site, $21.4 \%(37 / 173)$ of irritant dermatitis, $4.6 \%(8 / 173)$ of allergic dermatitis, and $1.2 \%(2 / 173)$ of tension injury. Among them, local infection accounted for the largest proportion in CASI type, and mechanical injury was relatively rare. Ullman et al. [4] reported that in CASI with 10,859 vascular pathways (PICC, CVC, Port, etc.), local infection or mechanical injury was relatively rare. The differences in these data may be related to our research methods, sample size and the particularity of the population. Therefore, the prevalence of CASI varies from care unit to care unit and from population to population, and the care of CASI is very important.

CASI related risk factors of PICC's patients in this study, disordered multiple Logistic regression analysis showed that PICC's patients were more likely to have CASI if they were aged, long catheter time, had diabetes, had moist and sweaty skin and had intermittent chemotherapy. 1) Age: The skin of the elderly is loose and thin, atrophic, and the moisturizing function declines, and the skin barrier function will weaken [5]; At the same time, elderly patients will appear aging and aging caused by self-care ability limited, cognitive dysfunction and other problems [6], leading to poor compliance with catheter maintenance, poor mastery of health education knowledge, and poor ability of self-management in home maintenance, etc. [7]. Some elderly patients are prone to malnutrition, resulting in the skin blood supply and nutritional status of patients affected, skin resistance decreased. Therefore, elderly patients are more likely to develop CASI. 2) Diabetes: Skin lesions are one of the most common complications of diabetes, and $33 \%-91 \%$ of diabetic patients will have one or more skin lesions [8]. Surgical wounds will be formed after PICC [1], and such exogenous wounds will cause skin injuries [9] [10]. At the same time, the epidermal thickness of diabetic patients was thinner, the epidermal layer was significantly reduced, the inflammatory mediators in local tissues were abnormally increased, and the biological behavior of epidermal keratinocytes was changed [11], making PICC's patients more prone to CASI. 3) Sweat: The skin is covered by a film for a long time, and the skin sweat accumulates and is not volatile under the fixation of the dressing [12]. In addition, the ordinary transparent dressing cannot remove the sweat, so the patient's skin chafes against the clothes, and the dressing tends to be moist, hemmed and sweaty, leading to an increased probability of skin allergy or skin reaction [13]. Seasonal changes affect the number of colonizing bacteria on the skin surface. Moist skin, higher oil content and higher temperature will lead to more colonizing bacteria on the skin surface [14]. In summer, patients' easy sweating will also cause CASI in PICC's patients. 4) Interval of chemotherapy: 
Zheng Yan [15] et al. conducted a study on family function and self-management of PICC's patients in Xinjiang during the interval of chemotherapy, and $31.88 \%$ of patients had poor self-management ability of PICC. $40.58 \%$ of those with medium level; $27.54 \%$ of the respondents were the better ones [15], the main reasons are as follows: catheter maintenance and inconvenience in surrounding towns and rural areas; The cause of the patient's illness, the length of the illness, the suffering of the disease [15]; The increase of economic burden, coupled with the deterioration of family functions [15] [16]; It reduces the catheter maintenance compliance of PICC's patients and increases the incidence of CASI in PICC's patients. 5) The tube time: When PICC catheter is inserted and surgical wounds are formed, fibrin sheath will surround them and a fibrous membrane will be formed, thus becoming a good parasitic site for microorganisms and not susceptible to the effects of host phagocytes and antibiotics [17] Skin colonized microorganisms migrate along the ducts and the patient may be at risk of local or systemic infection [18]. Therefore, the longer the PICC indwelling time, the higher the bacterial colonization rate of the catheter [14]. PICC retention time also affects CASI.

\section{Summary}

In summary, according to the age, diabetes, sweat, chemotherapy interval and catheter duration in PICC's patients in this study, CASI risk factors should be prevented, effective measures should be taken to improve the CASI related management system for nursing care, so as to reduce the incidence of CASI. Limitations of this study: The sample size was single and small, which could not completely represent the group of PICC's patients. This study is a descriptive study and only provides an objective description of the occurrence of CASI. In the future, a cohort study can be conducted in a more representative large sample population to investigate whether CASI has occurred or not, and to analyze and discuss influencing factors of CASI.

\section{Conflicts of Interest}

The authors declare no conflicts of interest regarding the publication of this paper.

\section{References}

[1] Broadhurst, D., Moureau, N. and Ullman, A.J. (2017) Management of Central Access Device-Associated Skin Impairment: An Evidence-Based Algorithm. Journal of Wound Ostomy \& Continence Nursing, 44, 211-220. https://doi.org/10.1097/WON.0000000000000322

[2] Wang, J., Gao, Y.F., Chen, W.F., et al. (2011) Influence of Different Application and Fixation on Contact Dermatitis after PICC Catheterization and Cost-Effectiveness Analysis. Chinese Journal of Nursing Management, 11, 88-90.

[3] Zhang, C. and Wang, C.L. (2015) Analysis of Causes of Exudation at the Puncture Point after PICC Catheterization and Nursing Countermeasures. Journal of Nurs- 
ing, 30, 47-48.

[4] Ullman, A.J., Mihala, G., O’Leary, K., et al. (2019) Skin Associated with Vascular Access Devices: A Secondary Analysis of 13 Studies Involving 10,859 Devices. International Journal of Nursing Studies, 91, 6-13. https://doi.org/10.1016/j.ijnurstu.2018.10.006

[5] Table-pfliger, J. (2004) The Skin Barrier: Reductions for the Wound Care, Part I. Advances in Skin \& Wound Care, 17, 417-425. https://doi.org/10.1097/00129334-200410000-00011

[6] Ge, X.X., Zhang, L.F. and Qian, Y.L. (2016) Risk Factors for Unplanned PICC Catheter Extubation in the Department of Oncology. Journal of Nursing Management, 16, 284-285.

[7] Xu, X.W., Yao, H.X., Lou, J.Q., et al. (2020) Analysis on Acceptance of Home Maintenance and Its Influencing Factors for Family Members of Elderly PICC Patients with Tube Discharge. Chinese Journal of Modern Nursing, 26, 2147-2151.

[8] Du, L., Lei, W.Z. and Chen, H.Y. (2016) Diagnosis and Treatment of Diabetes-Related Skin Lesions. World Clinical Medicine, 37, 86-92.

[9] Ge, X.J., Jiang, Y.Z. and Zhang, H.W. (2012) Diabetic Skin Tissue "Hidden Damage” Mechanism Research Progress. Chinese Journal of Burns, 28, 51-53.

[10] Thayer, D. (2012) Skin Damage Associated with Common Problems and Strategies for Prevention. Journal of Infusion Nursing, 35, 390-401. https://doi.org/10.1097/NAN.0b013e318270a91e

[11] Lu, S.L. (2003) Progress in Research on Mechanism and Treatment of Intractable Diabetic Wounds. Proceedings of the 5 th National Trauma Conference of the Chinese Medical Association, 52-54.

[12] Wang, Q., Chen, J. and Wei, L. (2019) A Cohort Study on the Influencing Factors of Medical Viscose Skin Injury at PICC Implantation Sites in Tumor Patients. Nursing Journal, 26, 1-5.

[13] Tan, H.M. and Feng, B.L. (2012) Effect Observation of 3M HP Transparent Dressing after PICC Catheterization. China Cosmetology, 21, 495.

[14] Ma, X.Y., Gao, Y.F., Wei, L.L., Zhang, H.Y., Chen, W.F., Fang, F., Chi, X.F. and Huang, Q. (2012) Investigation and Analysis of Influencing Factors of PICC Catheter-Related Infection in Tumor Patients. Chin J nosocomial infective sci, 22, 2290-2292.

[15] Zheng, Y., Fang, T.T., Tang, Y., et al. (2015) A Study on the Relationship between Family Function and Catheter Self-Management in Patients with PICC during Chemotherapy Interval in Xinjiang. Journal of Nursing Management, 15, 395-397.

[16] Hao, M., Ma, Y.L. and Song, H.N. (2015) Investigation and Analysis of Active Termination of PICC in Patients with Intermittent Chemotherapy. Journal of Chinese Nursing Management, No. 5, 551-554.

[17] Lu, B.Q., Chen, H.Y., Chen, P., et al. (2014) The Relationship between PICC Maintenance and Redness of Needle Eye and Indwelling Time at the Puncture Site. Journal of Nursing Advancement, No. 1, 19-21.

[18] O’Grady, N.P., Alexander, M., Dellinger, E.P., et al. (2002) Guidelines for the Prevention of Intravascular Catheter-Related Infections: Centers for Disease Control and Prevention. MMWR Recommendations and Reports, 51, 1-29. 